\title{
Occupational structure and socioeconomic inequality: a comparative study between Brazil and the United States *
}

\author{
Alexandre Gori Maia ** \\ Arthur Sakamoto ${ }^{* * *}$
}

\begin{abstract}
This paper explores how occupational structure is associated with economic inequality in Brazil in comparison to the United States. Changes in the Brazilian and American occupational structures between 1983 and 2011 are investigated in order to assess how closely they generate high socioeconomic inequalities. The effects of education, age, gender and race on occupational attainment are taken into account. Highlights of the results include: (1) a higher level of socioeconomic development in the American occupational structure, reflecting huge socioeconomic differences between these countries; (2) a tenuous convergence between the Brazilian and American occupational structures; (3) a significant decrease in the net impacts of education, age, gender and race on occupational attainment (i.e., reduced social stratification) in both countries. These results suggest the analytical worth of considering occupational structure as a significant intermediate variable affecting the level of socioeconomic inequality within a country over time, as well as between two countries at a given point in time.
\end{abstract}

Keywords: Occupations; Inequality; Labor market; Social stratification; Multinomial logistic model.

\section{Resumo}

Estrutura ocupacional e desigualdade socioeconômica: um estudo comparativo entre o Brasil e os Estados Unidos

Este trabalho analisa a contribuição da estrutura ocupacional como fonte de desigualdade no Brasil, fazendo um estudo comparativo com os Estados Unidos. Mudanças entre e dentro das estruturas ocupacionais são analisadas entre 1983 e 2011, verificando em que medida essas transformações contribuíram para atenuar os níveis de desigualdade socioeconômica. São consideradas diferenças de escolaridade, sexo, gênero e raça. Os resultados destacam: (1) um nível substancialmente superior de desenvolvimento da estrutura ocupacional nos Estados Unidos, refletindo as diferenças socioeconômicas entre os países; (2) uma tênue convergência entre as estruturas dos dois países no período; (3) uma expressiva redução das diferenças de escolaridade, idade, gênero e raça na inserção ocupacional dos dois países, ou seja, redução da estratificação social. O trabalho conclui sobre a relevante contribuição analítica da estrutura ocupacional como fator explicativo da desigualdade socioeconômica de um país ao longo do tempo ou entre países em um específico período de tempo.

Palavras-chave: Ocupações; Desigualdade; Mercado de trabalho; Estratificação social; Modelo logística multinomial.

JEL J21, J82, J62.

\footnotetext{
* Article received on August $13^{\text {rd }} 2013$ and approved on December $8^{\text {th }} 2014$. The authors would like to thank Capes (Coordenação de Aperfeiçoamento de Pessoal de Nível Superior) and Fapesp (Fundação de Amparo à Pesquisa do Estado de São Paulo) for supporting this research.

*** Professor - Universidade Estadual de Campinas / Instituto de Economia (Unicamp/IE), Campinas, SP, Brazil. E-mail: gori@unicamp.br.

**** Texas A\&M University / Department of Sociology, Texas, USA. E-mail: asakamoto@tamu.edu.
} 


\section{Introduction}

Occupational structure is undoubtedly implicated in a variety of socioeconomic phenomena relating to economic development and social inequalities (Blau; Duncan, 1967; Grusky; Sorensen, 1998). Since occupation reflects the individual's position in the technical division of labor, occupational structure is often construed to represent the pattern of socioeconomic opportunity in modern societies (Grusky; Hauser, 1984; Rose; Pevalin, 2001). Occupational structure also relates to the level of discrimination and segregation of various social groups (e.g., by gender and race) since occupational attainment is rarely determined solely by an individual's choice alone (Boskin, 1974; Brown et al., 1980; Filer 1986; Gill, 1989; Schimdt; Strauss, 1975). Moreover, changes in the occupational structure are related to changes in the demand for different occupational services due to socioeconomic development and technological advances (Blau; Duncan, 1967). Since technological development affects the division of labor, it impacts almost every aspect of the social structure (Williams, 1979).

The socioeconomic literature includes a vast array of studies relating to analyses of occupational stratification of various sorts (e.g., Grusky; Hauser, 1984; Wright, 1985, Goldthorpe, 2000, Rose; Pevallin, 2001; Quadros; Maia, 2010). Typologies for cross-national comparisons have also been developed (Treiman, 1977). Such studies have improved our understanding of the levels of social inequality between countries as well as between various social groups within countries (e.g., Szelényi 1992; Portes; Hoffmann, 2003; Rose; Harrison, 2009).

This paper analyzes the role of occupational structure as a source of socioeconomic inequality in Brazil in comparison to the U.S. Specifically, our analysis involves three main objectives: (1) to develop and utilize a method for the comparative study of occupational stratification in Brazil and the U.S. based on available data; (2) to investigate changes in the Brazilian and American occupational structures from 1983 to 2011; and (3) to assess differentials in education, age, gender and race as sources of occupational attainment, and thus social stratification. The U.S. is an informative comparison given that it remains the largest and most dynamic economy in the world, as well as being characterized by a high level of socioeconomic inequality. Comparing the U.S. to Brazil should provide further insight into the continuing evolution of economic development and social inequality in these countries.

\section{Prior literature on occupational stratification}

One of the main purposes of social stratification research is to study the process that generates inequality and the consequences of such inequality on individual behavior and social changes (Blau; Duncan, 1967; Sorensen, 1996). 
While many factors certainly affect inequality, occupation undoubtedly plays an important role in defining the social structure in modern societies. Occupation determines, to a large extent, current and future income opportunities, as well as often being associated with different levels of social honor, prestige and authority (Mills, 1956; Weeden, 2002). Occupations significantly influence the capacity of individuals to compete effectively in the market and their inclusion into society (Portes; Hoffmann, 2003; Mouw; Kalleberg, 2010).

The definition of occupational groups in the literature varies depending upon the data and research objectives considered in the analysis. For example, Erikson and Goldthorpe (1992) define a measure of bargaining power in employment relations which is determined by different combinations of employment status and occupations. The class schema that they proposed was also used by Rose and Pevallin (2001) to develop a new socioeconomic classification for the United Kingdom. Similarly, Wright (1985) proposes a class structure in the U.S. based on several levels of occupational skills and authority.

Special efforts have also been made to obtain common groups for crossnational comparisons. For example, Szelényi (1992) proposes a common occupational structure to compare the level of social inequalities in a socialist Hungary and in a capitalist society (the U.S.). Besides the individuals' position in the technical division of labor, this typology also considers their location in the social and historical organization of economic life. Portes and Hoffmann (2003) use an approach based on the control of key resources in the labor market (capital, means of production and labor force) to analyze the composition of class structures in Latin America. The comparison of the level of age and sex segregation among countries also frequently requires common typologies of occupational stratification, such as those proposed by Brinton and Ngo (1993) and Charles (1992). Similarly, comparative studies of social mobility are usually based on functional and similar occupational classes of comparison, even if they cannot be envisaged as forming a simple hierarchy (for instance, Erikson et al., 1979, Grusky; Hauser, 1984). A broader initiative has also been made to develop a common occupational structure and improve the understanding of differences in social structures and socioeconomic inequalities among member states of the European Union: the European Socio-economic Classification (ESeC), a typology based on the concept of employment relations (Rose and Harrison, 2009).

Since typologies are usually based on different theoretical assumptions and present different proposals, they are not directly comparable and no assertion about a relative superiority can be easily determined. The efficiency of each occupational structure will depend, above all, on the aim of the research. Generally, any attempt to reproduce complex social relations in a discrete number of occupational categories will result in an important loss of information. In turn, a proper typology of 
occupational stratification would play a central role in characterizing different levels of employment and, consequently, in determining different perspectives of socioeconomic patterns of life. Although these analyses do not necessarily imply the recognition of the primacy of occupations over other explanatory variables, they do emphasize the notion that occupation remains a significant and powerful determinant in many aspects of social life.

\section{Research methods}

\section{Data}

In order to compare the Brazilian and American occupational structures between 1983 and 2011, we use microdata from the Brazilian Pesquisa Nacional por Amostra de Domicílios (PNAD) and the American Current Population Survey (CPS). These data sets are based on well-known, nationally representative surveys for the respective countries. The PNAD is fielded by the IBGE (Instituto Brasileiro de Geografia e Estatística) while the latter is sponsored jointly by the U.S. Bureau of Labor Statistics and the U.S. Census Bureau. These two datasets are generally highly comparable in that they are large, cross-sectional household surveys with detailed information on demographic and economic characteristics.

In particular, the PNAD is a household sample collected annually ${ }^{1}$ and is nationally representative of Brazilian territory (with the slight exception of a few remote rural areas in six northern states which represented less than $3 \%$ of the Brazilian population in 2000 [IBGE 1995]) ${ }^{2}$. In recent years, the PNAD has been based on a sample with more than one hundred thousand households (representing more than four hundred thousand people) and has provided a huge and reliable source of information for socioeconomic analysis in Brazil. The questions in PNAD usually refer to activities conducted during the last week of September ${ }^{3}$.

CPS is a household sample survey applied monthly using a scientifically selected sample of some fifty thousand households in the U.S. (BLS 2000). Besides providing monthly information on the United States' labor force status, CPS also uses supplementary inquiries to collect additional and specific information from a variety of studies (BLS 2000). In order to analyze specific information about sociooccupational characteristics of the American working population, we use data from

(1) Between 1983 and 2011, the PNAD was not carried out in the years 1991, 1994, 2000, and 2010.

(2) Before 2004, the PNAD excluded the rural areas of the states of Rondônia, Acre, Amazonas, Roraima, Pará and Amapá. Since 2004, these areas have been added to the PNAD sampling frame; however, for the purpose of maintaining historical comparability, they were not considered in this study.

(3) With the exception of 1981, when the second week of September was adopted, and 1982, when a period between the last week of September and the second week of December was adopted. 
the Annual Social and Economic Supplement (ASEC). Information from the ASEC refers to activities conducted during the week which includes the 12th of March.

Important methodological changes have been implemented in the PNAD and the CPS, such as those related to the classification of occupations. Between 1970 and 2001, the PNAD used a common methodology to classify occupations. Since 2002, a new methodology has been used: CBO - Brazilian Occupational Classification (Dedecca; Rosandiski, 2003). In turn, CPS introduced the census occupational classification in January 1971, which remained until January 1983, when occupational and industrial information began to be coded using the 1980 classification systems. In January 2003, the 2002 Census Bureau's Occupational Classification System (OCS) was introduced in CPS (Bowler et al., 2010).

In both surveys, we considered as employed those who were 16 years or older and, during the reference week (a) did any work at all (for at least 1 hour) as a paid employee; worked in his/her own businesses, profession, or on his/her own farm; or worked 15 hours or more as an unpaid worker in an enterprise operated by a family member or (b) were not working, but who had a job or business from which he/she was temporarily absent. Those who worked in the Armed Forces were not considered in any of the surveys.

\section{Measurement of occupational structure}

Although occupational classifications used in Brazilian and American household surveys are not directly comparable, special efforts were made to create common groups of analysis. Occupations were classified based upon work performed, skills, education, training, and credentials. Since these concepts are very similar to those used by the Brazilian CBO and the American OCS, the groups primarily reflect the structure proposed by these systems (BLS, 2000; CBO, 2010). As a result, occupational codes of PNAD and CPS were aggregated into eight major occupational groups: 1) Managers; 2) Professionals; 3) Administrative support; 4) Sales; 5) Services; 6) Blue-collar workers; 7) Private household; 8) Farming. A complete description of the groups and their respective occupation codes in PNAD and CPS are presented in Table 1.

This classification assumes that occupations, classified in terms of principal duties, tasks, skills and technical know-how, define both individuals' economic opportunities and their position in the social structure (for example, Mills, 1956). Like other typologies of occupational stratification, it also considers different levels of possession and abilities, such as control over the labor of others and possession of scarce occupational skills (for example, Portes; Hoffmann, 2003; Wright, 1985). Some approaches were adopted to allow a comparison between Brazilian and American groups. For instance, until 2001, the PNAD had no specific information 
Table 1

Occupational groups, descriptions and occupation codes

\begin{tabular}{|c|c|c|c|c|c|c|c|}
\hline \multirow[b]{2}{*}{ Code } & \multirow{2}{*}{$\begin{array}{l}\text { Occupational } \\
\text { Group }\end{array}$} & \multirow[b]{2}{*}{ Description } & \multicolumn{5}{|c|}{ Occupation Codes } \\
\hline & & & PNAD 82-90 & PNAD 92-01 & PNAD 02-11 & $\begin{array}{l}\text { CPS 82- } \\
02\end{array}$ & CPS 03-11 \\
\hline 1 & Managers & $\begin{array}{l}\text { Executive, administrative and } \\
\text { managerial occupations } \\
\text { (excluding farmers) }\end{array}$ & $7-40$ & $7-40$ & 1111-1320; 4101-4102 & $\begin{array}{l}1-22 \\
303-307\end{array}$ & $\begin{array}{l}10-160 ; 220-430 \\
5000\end{array}$ \\
\hline 2 & Professionals & $\begin{array}{l}\text { Professional specialties, } \\
\text { technicians and related support } \\
\text { occupations }\end{array}$ & $\begin{array}{l}101-181 ; 193-233 ; 251- \\
293 ; 251-293 ; 302 ; 361 ; \\
401-406 ; 643 ; 711 ; 712 ; \\
761 ; 831-834 ; 918\end{array}$ & $\begin{array}{l}101-181 ; 193-233 ; 251- \\
293 ; 251-293 ; 302 ; 361 ; \\
401-406 ; 643 ; 711 ; 712 ; \\
761 ; 831-834 ; 918\end{array}$ & $\begin{array}{l}2011-2516 ; 2611-3132 ; 3137- \\
3411 ; 3421-3422 ; 3425-3426 ; \\
3531-3532 ; 3547 ; 3711-3722 ; \\
3732-3773\end{array}$ & $\begin{array}{l}43-242 \\
35-36 \\
255 ; 258\end{array}$ & $\begin{array}{l}1000-3540 ; 4820 \\
4930 ; 6660 ; 9030 \\
9040\end{array}$ \\
\hline 3 & $\begin{array}{l}\text { Administrative } \\
\text { support }\end{array}$ & $\begin{array}{l}\text { Administrative support } \\
\text { (including clerks) and } \\
\text { management-related } \\
\text { occupations }\end{array}$ & $\begin{array}{l}50-65 ; 182-192 ; 241- \\
244 ; 646 ; 771-776\end{array}$ & $\begin{array}{l}50-65 ; 182-193 ; 241- \\
244 ; 646 ; 771-776\end{array}$ & $\begin{array}{l}4110-4152 ; 2521-2525 ; 3511- \\
3515 ; 3523-3525 ; 3542 ; 3723 ; \\
3731 ; 4201 ; 4212 ; 4214 ; \\
4221-4223 ; 4231 ; 4241\end{array}$ & $\begin{array}{l}23-34 \\
37-42 \\
308-402\end{array}$ & $\begin{array}{l}500-950 ; 5010- \\
5940\end{array}$ \\
\hline 4 & Sales & Sales occupations & $601-642 ; 644 ; 645$ & $601-642 ; 644 ; 645$ & $\begin{array}{l}2531 ; 3517 ; 3541 ; 3543 \\
3544 ; 3545 ; 3546 ; 3548 \\
4211 ; 5201-5243\end{array}$ & $\begin{array}{l}243-254 \\
256-257 \\
259-302\end{array}$ & $4700-4965$ \\
\hline 5 & Services & $\begin{array}{l}\text { Protective and service } \\
\text { occupations, excluding private } \\
\text { households }\end{array}$ & $\begin{array}{l}801-826 ; 853-859 ; 912- \\
913 ; 915-917 ; 919 ; 926\end{array}$ & $\begin{array}{l}801-827 ; 851-852 ; 863- \\
869 ; 912-913 ; 915-917 \\
919 ; 926-927\end{array}$ & $\begin{array}{l}\text { 401-513; 4213; 3518; 3522; } \\
5101-5111 ; 5114-5134 ; 5151- \\
5191 ; 5198-5199\end{array}$ & $\begin{array}{l}413-472 ; \\
486 ; 487 \\
875\end{array}$ & $\begin{array}{l}3600-4010 ; 4020- \\
4160 ; 4210 ; 4240- \\
4550 ; 4620-4640 ; \\
9720\end{array}$ \\
\hline 6 & $\begin{array}{l}\text { Blue-collar } \\
\text { workers }\end{array}$ & $\begin{array}{l}\text { Operators, manufacturers, } \\
\text { laborers and precision } \\
\text { production, craft and repair } \\
\text { occupations }\end{array}$ & $\begin{array}{l}341-351 ; 371-391 ; 411- \\
589 ; 721-753 ; 762 ; 841- \\
845 ; 911 ; 914 ; 920-925\end{array}$ & $\begin{array}{l}341-351 ; 371-391 ; 411- \\
589 ; 721-753 ; 762 ; \\
841-845 ; 911 ; 914 ; \\
920-925\end{array}$ & $\begin{array}{l}3134-3136 ; 3412-3413 ; 3423- \\
3424 ; 3516 ; 3911-3912 ; 5112 \\
5141 ; 5142 ; 5192 ; 7101-9922\end{array}$ & $\begin{array}{l}503-874 \\
876-906\end{array}$ & $\begin{array}{l}6200-6650 ; 6700- \\
9000 ; 9110-9650 \\
9730-9750\end{array}$ \\
\hline 7 & $\begin{array}{l}\text { Private } \\
\text { household }\end{array}$ & $\begin{array}{l}\text { Private household cleaners, } \\
\text { servants, launderers and related } \\
\text { occupations }\end{array}$ & 544 & $\begin{array}{l}\text { employment status code } \\
=2\end{array}$ & employment status code $=2$ & $403-412$ & $\begin{array}{l}4020 ; 4200 ; 4220- \\
4230 ; 4600-4610 ; \\
4650\end{array}$ \\
\hline 8 & Farming & $\begin{array}{l}\text { Farming, forestry and fishing } \\
\text { occupations. }\end{array}$ & $1-6 ; 301 ; 303-336$ & $1-6 ; 301 ; 303-336$ & $6110-6430$ & $\begin{array}{l}473-485 \\
488-502\end{array}$ & $\begin{array}{l}200-210 ; 6000- \\
6130\end{array}$ \\
\hline
\end{tabular}


on managerial positions, and as a result, most Brazilian employers were included in the managerial group. As suggested by Szelényi (1992), this analysis assumes that Brazilian managers perform identical functions in the social division of labor, managing similar amounts of authority in the workplace or sharing comparable levels of prestige in relation to other occupational groups. A relevant difference of this typology in comparison to other occupational structures is that it considers private household workers as a group apart, due to their significant representativeness in Brazilian society. Overall, the comparison can be considered reasonable, since there is a relative consistency among the most common occupations for each group in Brazil and in the U.S. (Appendix A).

Although these eight occupational classes are not exactly social groups in the conventional sense of the term, the assumption is that their members share relatively similar life chances, social experiences and social networks (Blau; Duncan, 1967). In addition, the hierarchy of occupational classes does not represent a scalar measure of social differences, but, above all, an approximation of social standards defined by the position of workers in the labor market. In other words, although some groups are subordinated to others, such relationships cannot be quantified.

\section{Statistical models}

Besides descriptive analyses, the results also considered the multiple relationships between occupational attainment and a set of personal characteristics, such as the level of education, age, gender and race. A multinomial logistic model was estimated for each country using pooled data from 1983 to $2011^{4}$. The dependent variables were associated to the odds of belonging to one of the 8 occupation groups, numbered from 1 to 8 according to the codes presented in Table 1 . Since the $6^{\text {th }}$ group (blue-collar workers) was considered as the reference in the multinomial logistic, the odds represent how much greater the probability of belonging to a specific occupational group is in comparison to belonging to the blue-collar group. In other words, the models were given by:

$$
\ln \left(P_{h_{i t}} / P_{6_{i t}}\right)=\beta_{h 0}+\sum_{j=1}^{k} \beta_{h j} X_{j_{i} t}+\delta_{h 0} \text { year }_{t}+\sum_{j=1}^{k} \delta_{h j} X_{j_{i t}} \times y e a r_{t}+e_{i t}
$$

Where $h=1,2,3,4,5,7,8$ is the $h$-th occupational group, $i=1 . . n$ is the $i$-th person, $t=0 . .23$ is the time period, $P_{j_{i t}}$ is the probability for the $i$-th person belonging

(4) Besides the absence of data from the PNAD in the years 1991, 1994, 2000, and 2010, the pooled sample used in the multinomial logistic model for Brazil did not consider the years 1983, 1984, 1985 due to missing information on race. 
to the $h$-th occupational group in the period $t, X_{j_{i t}}$ is the $j$-th socioeconomic characteristic for the $i$-th person in the period $t$, year is the time period variable (year $=0 . .23$ ), and $e$ is the unpredicted error. While the coefficients $\beta$ express the variation in the logarithm of the odds (logit) given a unit variation in $X$, the coefficients $\delta$ represent changes in these relations over the years.

We considered the following explanatory factors:

i) Race: a dummy variable Black which is equal to 1 for black people (selfdeclared answer), 0 otherwise (White, Brown, Asian, Indian, among others);

ii) Gender: a dummy variable Female which is equal to 1 for women, 0 for men;

iii) Education: three dummy variables in order to discriminate four levels of educational attainment - Superior (1 for those with superior diploma), Secondary (1 for those who completed the secondary education), Elementary (1 for those who completed elementary school); less than elementary education as reference of analysis;

iv) Age: three dummy variables in order to discriminate four age groups - 16 to 24 years used as reference, 25 to 39 (1 for those between 25 and 39 years old), 40 to 59 ( 1 for those between 40 and 59 years old), 60 or more ( 1 for those of 60 years old or more).

Besides predicting patterns of employment, the results of the multinomial logistic model can also be interpreted as a measure of gender and race segregation (Schmidt and Strauss, 1975). Significant estimates for gender and race coefficients suggest differential access to specific occupational groups, independent of the productivity characteristics, such as age and educational attainment. However, these results must be interpreted with caution, given that differences may also reflect gender and race preferences for different groups of occupations.

\section{Empirical results}

\section{Occupational structures compared}

The two biggest populations and economies in America, Brazil and the U.S., highlight huge differences in their stage of socioeconomic development and, consequently, in their occupational structures. One of the most significant differences is the extensive participation of low socioeconomic status occupations in Brazil, such as agricultural and private household workers (Figures 1 and 2).

Although agricultural automation markedly reduced the participation of agricultural workers in the Brazilian occupational structure between 1983 and 2011 
(a reduction of 14 percentage points in this period), they still represented 11 percent of the Brazilian workforce in 2011. In Brazil, the most frequent occupation in this group is the unskilled worker on farms (33 percent of the total number of workers were in this group), usually seasonal or unpaid workers contributing to low productivity. In the U.S., there were less than 2 million farm workers in 2011, representing only 1 percent of the occupational structure. The number of agricultural workers decreased substantially in this country between the "40s and the ' $80 \mathrm{~s}$, as a result of advanced technological growth and rising returns to nonfarm labor (Barkley, 1990).

Domestic work is also largely related to informality and other precarious working conditions. Unskilled maids comprise the majority of this group, and represented 6.5 million people in Brazil, or 7.5 percent of the occupational structure in 2011. In the U.S., domestic workers make up a very small share of the occupational structure, representing less than 1 million workers in 2011.

The next groups in the occupational hierarchy are the blue-collar and service workers. Blue-collar workers (those in manual jobs and highly routinized activities) are present in both countries and two of the most prevalent occupations in this group are truck drivers and construction laborers. Within this group we can also highlight important particularities in each country. For instance, in the U.S. there is a higher participation of occupations related to industrial activities, such as laborers and automotive mechanics. In Brazil, these occupations are largely related to unskilled and informal activities, such as masons, conservation and maintenance workers.

Service occupations represent low-skilled and low-wage positions in the service sector of the economy. They differ from the blue-collar workers by the activities they do rather than their wage or social status. In Brazil, they are especially related to informal activities, such as hairdressers, cooks and waiters, representing 11.5 percent of the occupational structure. Service workers are more representative in the U.S., where they made up 17 percent of the occupational structure in 2011, predominantly represented by janitors and building cleaners (excluding domestic workers), cooks and nursing aides.

The more recent development of trades in urban areas and big chains of wholesale and retail stores in Brazil also meant an increasing participation of sales occupations in its occupational structure. This group consists of cashiers, sales representatives, real estate agents and a diversity of sales workers whose socioeconomic status is closely related to the kind of customers they have. In Brazil however, the extensive participation of sales workers (14 percent of the occupational structure in 2011) is determined by the large number of informal and precarious jobs in this category, such as peddlers (1.1 million people) and door-to-door salesmen 
(0.4 million), representing a way out for these unskilled workers, for lack of better opportunities in the labor market.

Administrative support occupations are one of the most representative groups of the white-collar middle class, and they are particularly relevant in the U.S. As a result of systematization, many administrative activities have become routine, introducing a diversity of occupational categories and hierarchies in offices. Secretaries, receptionists and auditing clerks are some of the representative occupations in this group, which corresponded to 16 percent of the occupational structure in the U.S. and 10 percent in Brazil in 2011.

Professionals and managers are in the upper bound of the occupational structure. Regardless of where they have direct ownership over the capital, managers run large and medium private or public firms and institutions. They control organized labor forces and usually receive the highest average wages (Portes; Hoffmann, 2003). Below them, the professional skilled workers, usually with a university degree, are those employed by private or public institutions in order to assume positions of high responsibility. In addition to administrative support occupations, managers and professionals are the dominant class in the U.S. (50 percent in 2011), which reflects a more advanced level of development of the American occupational structure (these occupations represented just 27 percent in Brazil).

\section{Figure 1}

Percentage of workers by occupational group - Brazil 1983 to 2011

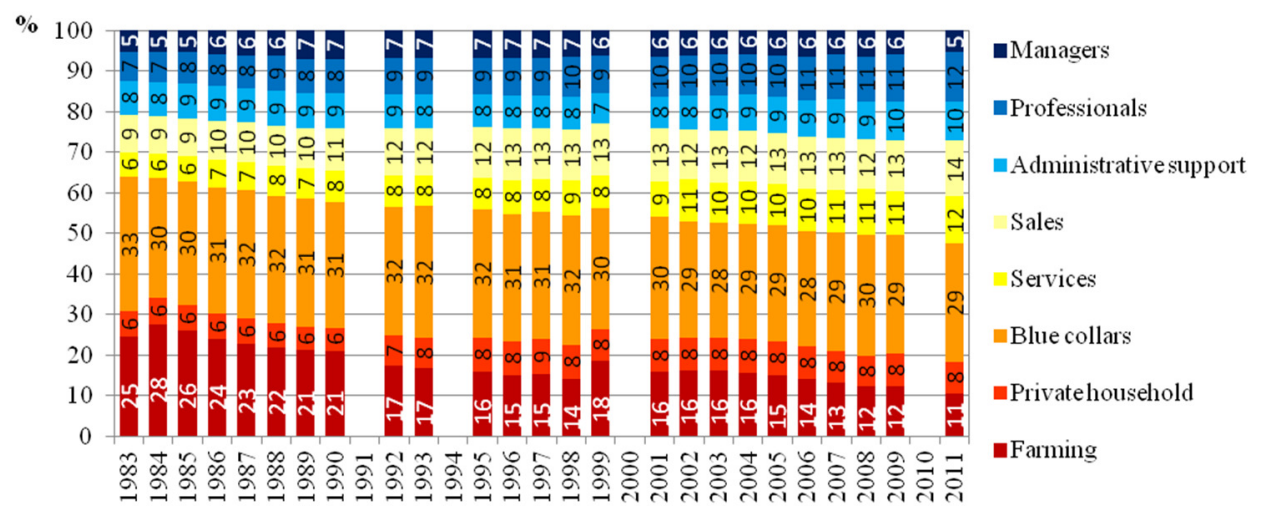

Source: PNAD. 
Figure 2

Percentage of workers by occupational group -US 1983 to 2011

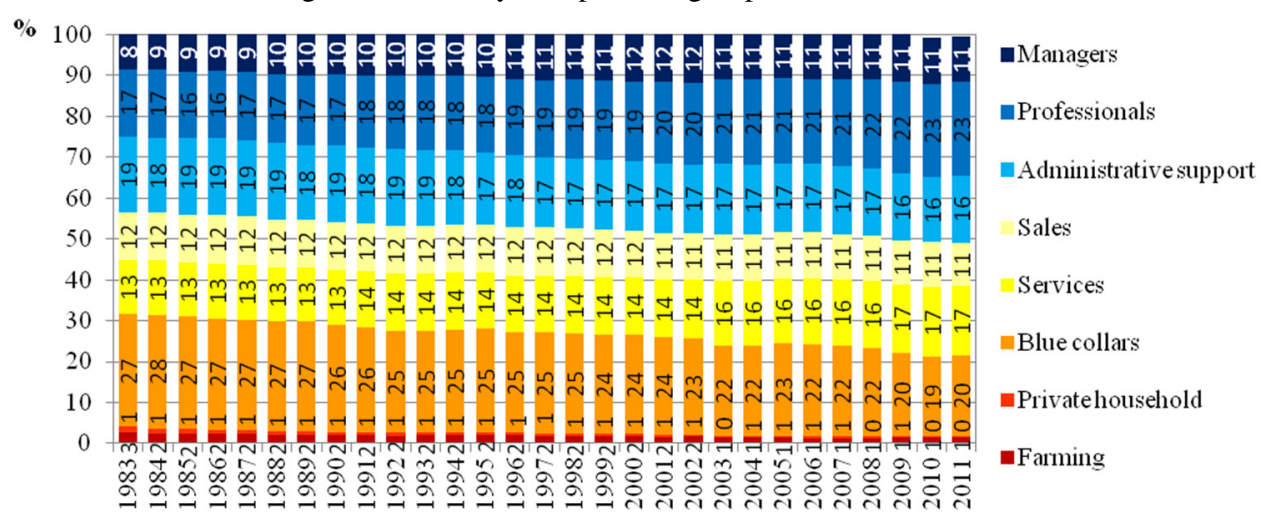

Source: CPS, March supplement.

The distribution of workers in the top, middle and bottom groups of the occupational structure may help explain, to a large extent, the levels of socioeconomic inequality. For example, based on a similar methodology of occupational stratification, Maia (2013) finds that differences between the eight occupational groups represent a quarter of the total wage inequality in Brazil. These results reflect the hierarchy of huge differences in the average wages among the large bottom and the small top occupational groups. When the analysis is disaggregated to consider differences between all of the 481 occupational codes, the explanatory power rises to $45 \%$. The other $55 \%$ can be explained by individual differences within the same occupation. The level of wage inequality between occupational groups is also high in the U.S., although to a lower degree than in Brazil. For example, Kim and Sakamoto (2008) report that differences between 331 occupations explain just $25 \%$ of the total wage inequality in the U.S. In short, intra-occupational inequality is relatively higher in the U.S. $(75 \%)$.

The most notable change in the Brazilian occupational structure between 1983 and 2011 was the substantial reduction of agricultural workers and the rise of service workers, most of them in informal positions, such as hairdressers and cooks. In the U.S., changes were largely related to the reduction of blue-collar workers and an increase in a new generation of skilled professional workers. The participation of professionals increased by 6 percentage points during this period. Within this group in the U.S., the number of computer system analysts increased by more than 1.5 million between 1983 and 2002. Since 2003, new subcategories were considered in the computer-related occupation which, together, represented 3.3 million people in 2011. 
Convergence or divergence trends between the Brazilian and the American occupational structures can be analyzed in Figure 3. The horizontal axis represents the cumulative percentage of Brazilian workers in the occupational groups ranked according to their respective socioeconomic status (from farming to managers). The vertical axis represents the respective cumulative percentage for the American workers. If workers were equally distributed among Brazilian and American occupational groups, the relation would be represented by a straight line at a 45 degree angle. However, because the polarization of workers in low status occupational groups is higher in Brazil than in the US, this relation tends to be represented by a curve under the 45-degree line. The closer the relation is to the horizontal axis, the more divergent the occupational structures are.

\section{Figure 3}

Accumulated distribution of workers by occupational group - Brazil and US, 1983 and 2011

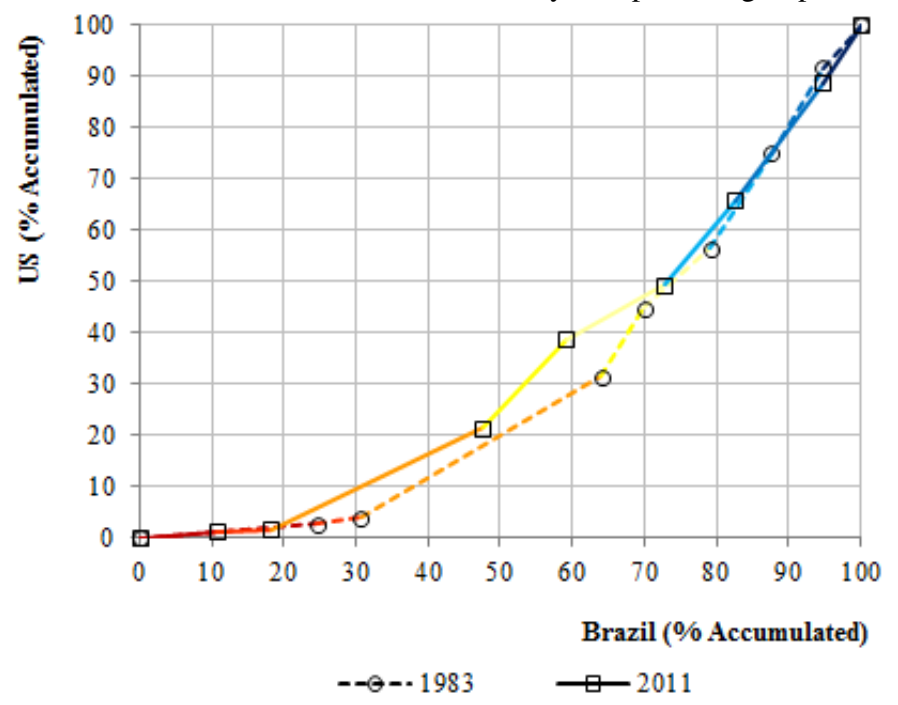

- Managers

- Professionals

- Adm inistrative support

Sales

Services

Inlue collars

- Private household

- Farming

Source: CPS, March supplement.

The relations expressed in Figure 3 suggest a tenuous convergence of the Brazilian and American occupational structures between 1983 and 2011, particularly due to the substantial decline in low-status groups and the increase in intermediate occupational groups in Brazil. For instance, the cumulative participation of farming, private households, blue-collar work and service work declined faster in Brazil than in the U.S. In Brazil, these occupations shifted from 70 to 59 percent between 1983 and 2011 and, in the U.S., from 45 to 38.5 percent. On the other hand, the cumulative participation of managers and professionals increased more in the U.S. than in Brazil ( 9 and 5 percentage points, respectively). 


\section{Occupational attainment}

In the following section we analyze the impacts of socioeconomic characteristics such as gender, race, age and education on occupational attainment in Brazil and in the U.S. Besides reflecting different levels of occupational segregation, differences may also represent cross-national disparities in occupational demand or differential occupational preferences in each country. Because the PNAD omitted information on race between 1983 and 1985, our investigation for this country refers to the period from 1982 to 2011 (not including 1983 to 1985). Regarding the U.S., our analysis refers to the entire period from 1983 to 2011.

The distribution of workers according to occupational groups and socioeconomic characteristics is presented in Appendix B. First, the low level of education of the Brazilian working population is obvious. Despite the participation of workers with a secondary diploma or more having tripled since 1982, these workers still represented just 51 percent of the Brazilian working population in 2011. In the U.S., by contrast, 91 percent of workers held a secondary diploma. Within occupational groups with a lower socio-occupational status (such as private household and farming workers), workers with a secondary diploma were mostly inconsequential in Brazil whereas they represented more than 70 percent in all of the American occupational groups in 2011.

The demographic transition is more developed in the U.S., therefore there is a higher share of older workers when compared to Brazil. Notably, those of 50 years of age or older, who represented $32 \%$ of the working population in the U.S., made up just $20 \%$ of the working population in Brazil in 2011. These workers are mainly classified among managers and farm workers. In the former group, the prevalence of older workers is mainly influenced by their higher levels of occupational experience. In the latter, the prevalence is mainly affected by the exodus of younger workers to the urban areas. As a result of these demographic dynamics, the share of young workers (between the ages of 16 and 29) is particularly low among farm workers in both countries (24\% in Brazil and $20 \%$ in the U.S. in 2011).

The share of women in the Brazilian labor force is significantly lower than in the US (a difference of 5 percentage points) despite the substantial increase of 9.5 percentage points between 1982 and 2011. In the U.S., female participation has increased sharply since the end of World War II (Shank, 1988), so much so that in 1983 women already accounted for 44 percent of the labor force in this country (while in Brazil they accounted for just 32 percent). In both countries, female participation is particularly high among private household workers, administrative support and professional occupations. Domestic work remains as one of the few job 
opportunities for many women, especially migrants from less developed areas, who have little or no formal education. In turn, women with some level of education attainment fill important positions in administrative support and professional occupations, especially as nurses, secretaries and elementary school teachers (Howe, 1977).

Although black workers present similar participation in the Brazilian and American labor forces ( 9 percent in Brazil and 11 percent in the U.S. in 2011), there are significant differences in their distribution among the occupational groups. In Brazil, they are mainly concentrated in private household and farming occupations, usually related to informal activities, including vulnerable self-employment and underemployment (Maia; Garcia, 2007). In the U.S., they prevail mainly in service and administrative support occupations. According to Tomaskovic-Devey et al. (2006), the shift to a service economy marginally contributed to the reduction in the black-white segregation in the U.S., especially in less desirable retail trade activities.

Several factors may help explain the differences in the labor participation in the occupational groups, such as occupational choice, discrimination or the workers' socioeconomic characteristics. The following analyses identify the net effect of socioeconomic characteristics on occupational attainment, highlighting how characteristics related to age, education, gender, and race independently affect occupation choice and/or social discrimination. These analyses help explain, for example, whether the polarization of black workers in low paid occupations is due to their socioeconomic characteristics, such as age and education, or due to segregation and race preferences.

The Wald chi-square statistic was used to test the global null hypothesis that all of the predictors in either of the models (equation 1) have zero coefficients (row Overall Model in Table 2). Results indicate that the models for both Brazil and the U.S. fit significantly at the $0.01 \%$ level. This means that the models have at least one non-zero coefficient. The Wald chi-square statistics were also applied to test the null hypothesis that there is no relationship between each predictor independently and occupational attainment. The degrees of freedom (d.f.) reveal how many variables were used to represent each predictor factor in the logistic models. All predictors are significant at the $0.01 \%$ level, including the interaction between time and socioeconomic characteristics. In other words, all predictors have significant marginal effects and there are structural changes in the relation between socioeconomic characteristics and occupational attainment. 
Occupational structure and socioeconomic inequality: a comparative study between Brazil and the USA

Table 2

Model Fit Statistics (Wald Chi-Square) and Tests of Effects for the Multinomial Logistic Models Brazil and the U.S. 1982 to 2011

\begin{tabular}{|c|c|c|c|c|c|c|}
\hline \multirow{2}{*}{ Source } & \multicolumn{3}{|c|}{ Brazil } & \multicolumn{3}{|c|}{ U.S. } \\
\hline & d.f. & Chi-Square & $\mathrm{p}$ & d.f. & Chi-Square & $\mathrm{p}$ \\
\hline Year & 7 & $1,936.6$ & $<.0001$ & 7 & 611.7 & $<.0001$ \\
\hline Black & 7 & $4,140.6$ & $<.0001$ & 7 & $6,017.6$ & $<.0001$ \\
\hline Black $\times$ Year & 7 & 769.3 & $<.0001$ & 7 & $1,084.9$ & $<.0001$ \\
\hline Female & 7 & $89,931.0$ & $<.0001$ & 7 & $78,587.5$ & $<.0001$ \\
\hline Female $\times$ Year & 7 & $6,265.9$ & $<.0001$ & 7 & $2,191.8$ & $<.0001$ \\
\hline Education & 21 & $199,693.9$ & $<.0001$ & 21 & $132,001.0$ & $<.0001$ \\
\hline Education $\times$ Year & 21 & $12,375.0$ & $<.0001$ & 21 & $3,282.2$ & $<.0001$ \\
\hline Age & 21 & $27,102.6$ & $<.0001$ & 21 & $16,075.8$ & $<.0001$ \\
\hline Age $\times$ Year & 21 & $5,226.9$ & $<.0001$ & 21 & $3,179.4$ & $<.0001$ \\
\hline Overall Model & 119 & $1,341,525.9$ & $<.0001$ & 119 & $840,333.4$ & $<.0001$ \\
\hline
\end{tabular}

Source: Pesquisa Nacional por Amostra de Domicílios (PNAD) and Current Population Survey (CPS), March supplement.

Table 3 (Brazil) and Table 4 (U.S.) show the maximum likelihood estimates for the multinomial logistic coefficients (i.e., the estimates for $\beta$ and $\delta$ in equation 1). Estimates not significant at the 5\% level are represented by the superscript symbol "+". Because blue-collar workers are used as the reference, the estimates reflect the impact of each personal characteristic on the chance of being in a specific occupational group when compared to the chance of being in the blue-collar group. 
Table 3

Maximum Likelihood Estimates for Multinomial Logistic Model - Brazil 1982 to 2011

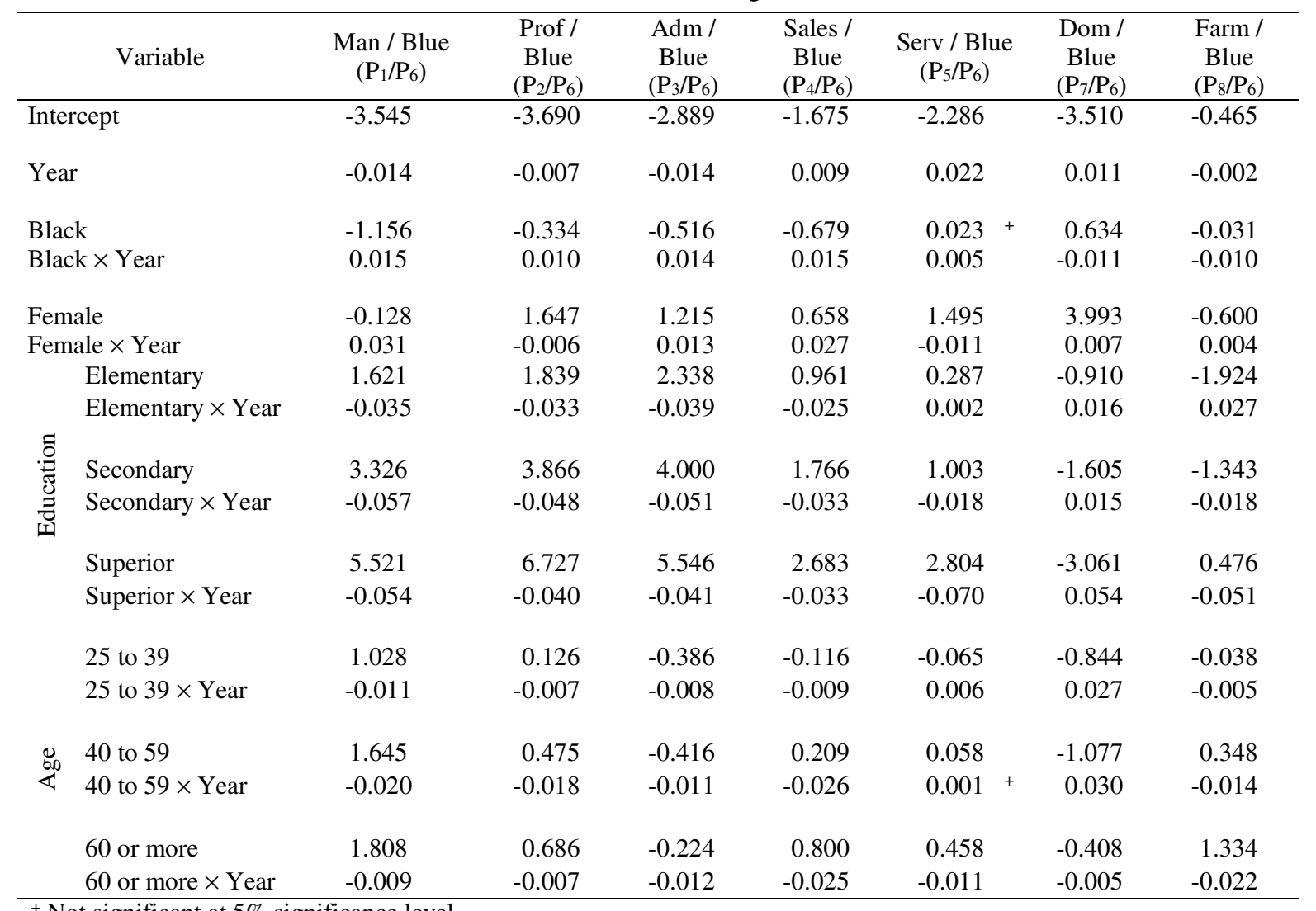

${ }^{+}$Not significant at $5 \%$ significance level
Source: Pesquisa Nacional por Amostra de Domicílios (PNAD), IBGE.

Economia e Sociedade, Campinas, v. 24, n. 2 (54), p. 229-261, ago. 2015. 
Table 4

Maximum Likelihood Estimates for Multinomial Logistic Model - U.S. 1983 to 2011

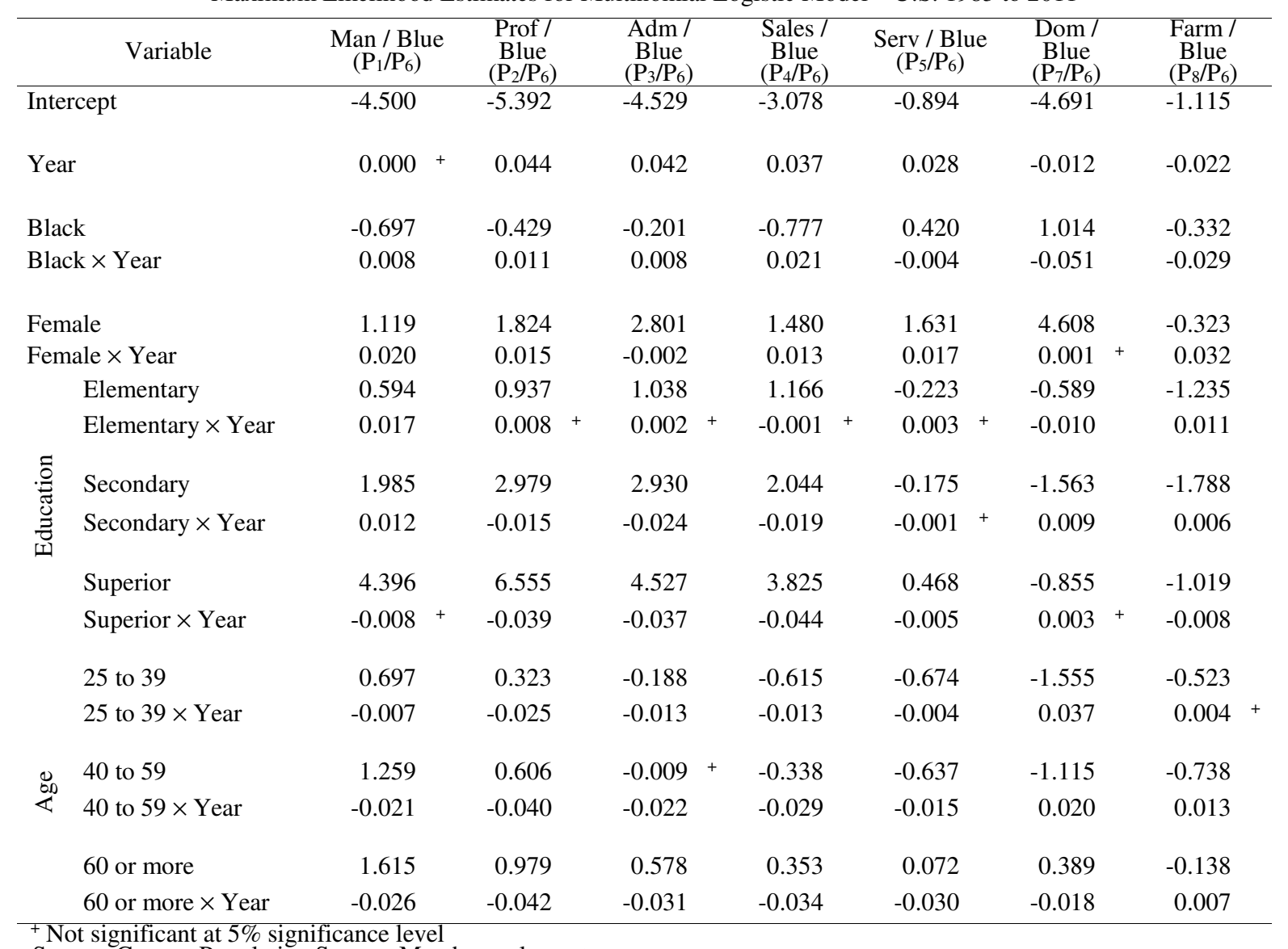

Source: Current Population Survey, March supplement. 
In both countries, the level of education shows the most impressive impact on occupational attainment. The preponderance of a consistent hierarchy of values in the multinomial logistic estimates indicates that more education renders the person more likely to be in a high-prestige occupational group as opposed to a low-prestige occupational group, holding other personal characteristics constant. For instance, professionals, administrative support and managers are, respectively, the occupational groups where higher educated workers are more likely to be employed (with the highest effects of secondary and superior diploma on logit) in comparison to farming, private household and blue-collar groups, where they are less likely to be employed (with the lowest effects of secondary and superior diploma on logit).

Elementary and secondary education used to have a greater impact on occupational attainment in Brazil, since most workers in this country had low levels of education in the 1980s (75 percent of the workers had less than an elementary education in 1982). However, estimates for the interaction between socioeconomic characteristics and the time variable (year) suggest a sharp decrease in the impact of education on occupational attainment, especially in Brazil. In other words, education had a greater impact on occupational attainment in the 1980s than in the 2000s. Since more people are attaining a secondary or college diploma, even in low-prestige occupational groups, marginal returns of education on occupational attainment tend to decrease. Moreover, marginal returns decreased faster in Brazil, especially for elementary and secondary diploma levels, since education increased relatively faster in this country.

The effect of age, which reflects differences between generations as well as being a proxy for the working experience, on occupational attainment is not so intuitive. In both countries, the highest ranked occupational groups, managers and professionals, tend to present a positive relation with age. In other words, holding others factors constant, the older the worker, the more likely he/she is to be a manager or a professional in comparison to other occupational groups. Another interesting result is the significant reduction in the impact of age differentials on occupational attainment in both countries, especially in the U.S. Age had a greater impact on occupational attainment in the 1980s than in the 2000s. This result is similar to that obtained for education, and suggests a substantial fall in marginal returns of age, experience and/or generation differentials on occupational attainment, which could be related to demographic changes in both countries (i.e., population aging).

A substantial gap between male and female occupational attainment still persists in both countries. Holding other factors constant, women are more likely to be, above all, in the private household group. Secondarily, women are more likely to be in intermediary groups, such as professional, administrative support, sales and services. Female participation is also relatively low in the American blue-collar 
group (14 percent in 2011) which is the reference group of analysis. Between the 1980 s and the 2000s, the occupational attainment of women increased in both countries, particularly among managers and sales workers. In the U.S., it also increased significantly among professional workers.

Black workers are also associated with low-prestige occupational groups in both countries. Holding other socioeconomic characteristics constant, black workers are more likely to be in the service, blue-collar, and domestic worker groups. Moreover, there were substantial reductions in the differences of occupational attainment in both countries, especially in Brazil, which may suggest a decreasing level of segregation. In Brazil, the reduction was more pronounced in the managerial, professional, administrative support and sales groups. For example, the ratio between the chance of a black worker being a professional rather than blue-collar worker increased by more than one percentage point per year between 1982 and 2011. Nevertheless, in 2011 the black population remained underrepresented in the four main occupational groups (managers, professional, administrative support and sales) in both countries.

\section{Final considerations}

Occupational structure is an important component in the analysis of socioeconomic inequality. Occupations substantially affect current and future economic opportunities and are furthermore associated with different levels and patterns of socioeconomic development. Since similar occupational groups may present distinct socioeconomic patterns, the occupational structure cannot, however, be the only analytical instrument to understand inequality, especially when comparing highly heterogeneous societies like Brazil and the U.S. Nevertheless, the comparison between these countries provided important analytical elements to understand divergences and convergences in the patterns of inequalities and socioeconomic development.

Regarding occupational structure in Brazil, there is a greater degree of polarization towards less-skilled occupational groups. The high participation of farming, private household workers and other types of low-prestige occupations reflects, among other things, an economy that is highly dependent on commodity production. It is also associated with a low level of productivity as well as educational and human capital training in its labor force. On the other hand, upper level occupational groups (managers, professionals and administrative support) prevail in the American occupational structure and reflect an economy which is more specialized in technologically advanced production with continuous flows of innovation. 
During the 1980s and the 2000s, changes in the Brazilian occupational structure were largely related to a major reduction in the number of agricultural workers and the rise of service workers, most of them in informal positions. In the U.S., changes were largely related to the reduction of blue-collar workers and the emergence of a new generation of skilled professional workers, reflecting the fast transition of this country to the so-called New Economy. Overall, changes led to a tenuous convergence between the Brazilian and American occupational structures, especially due to the faster decrease of low status groups and the increase in intermediate occupational groups in Brazil.

The effects of age, education and race on the occupational attainment reduced substantially between 1983 and 2011. These effects declined faster in Brazil, especially for elementary and secondary education, reflecting a significant improvement at the basic levels of education in the country. Despite a relative improvement in recent decades, educational attainment in Brazil remains substantially lower than in the U.S., even in lower-status occupational groups. Moreover, the participation of female workers is higher in the U.S. especially in white-collar and other high prestigious occupational categories. Racial segregation by occupation persists as a major source of social inequality in both countries, although there has been a relative improvement in recent periods.

Brazil is widely known for its high levels of poverty and inequality, which is closely related to the historical unfolding of its socioeconomic development. Since colonization, and with few structural changes until recent years, Brazil has witnessed a huge accumulation of wealth by a restricted number of people in addition to high levels of social exclusion. Socioeconomic development experienced in the last decades seems to have attenuated to some extent the extreme level of social inequality in this country, especially in relation to the effects of education, age and race on occupational attainment. Nevertheless, the occupational structure in Brazil reflects its relative level of economic underdevelopment in relation to its American counterpart, even though their social groups appear to be subject to similar levels of high inequalities in regard to occupational attainment.

\section{References}

BARKLEY, Andrew. Determinants of the migration of labor out of agriculture in the United States, 1940-85. American Journal of Agricultural Economics, v. 72, n. 3, p. 567-573, 1990.

BLAU, Peter M.; DUNCAN, Otis Dudley. The American occupational structure. New York: John Wiley \& Sons, 1967.

BOSKIN, Michael J. A conditional logit model of occupational choice. The Journal of Political Economy, v. 82, n. 2, p. 389-398, 1974. 
BOWLER, Mary; RANDY, E. Ilg; MILLER, Stephen; ROBISON, Ed; POLIVKA, Anne. Revisions to the current population survey effective in January 2003. Bureau of Labor Statistics. Retrieved December 28, 2010. Available from: http:// www.bls.gov/cps/rvcps03.pdf.

BRINTON Mary C.; HANG-YUE, Ngo. Age and sex in the occupational structure: a United States-Japan comparison. Sociological Forum, v. 8, n. 1, p. 93-111, 1993.

BROWN, Randall S.; MOON, Marilyn; ZOLOTH, Barbara S. Occupational attainment and segregation by sex. Industrial and Labor Relations Review, v. 33 , n. 4, p. 506-517, 1980.

BLS. Design and methodology: current population survey. Bureau of Labor Statistics, 2000 (Technical Paper, 66).

CBO. Classificação Brasileira de Ocupações: CBO - 2010. 3. ed. Brasília: MTE, SPPE, 2010.

CHARLES, Maria. Cross-national variation in occupational sex segregation. American Sociological Review, v. 57, n. 4, p. 483-502, 1992.

DEDECCA, Claudio S.; ROSANDISKI, Eliane. Sensos e dissensos: as inovações metodológicas do Censo Demográfico 2000. Revista da ABET, v. 3, n. 2, p. 30-60, 2003.

ERIKSON, Robert; GOLDTHORPE, John H. The constant flux: a study of class mobility in industrial societies. Oxford: Clarendon Press, 1992.

; PORTOCARERO, Lucienne. Intergenerational class mobility in three Western European societies: England, France and Sweden. The British Journal of Sociology, v. 30, n. 4, p. 415-441, 1979.

FILER, Randall K. The role of personality and tastes in determining occupational structure. Industrial and Labor Relations Review, v. 39, n. 3, p. 412-424, 1986.

GILL, Andrew M. The role of discrimination in determining occupational structure. Industrial and Labor Relations Review, v. 42, n. 4, p. 610-623, 1989.

GOLDTHORPE, John H. On sociology: numbers, narratives, and the integration of research and theory. Oxford: OUP, 2000.

GRUSKY, David B.; HAUSER, Robert M. Comparative social mobility revisited: models of convergence and divergence in 16 countries. American Sociological Review, v. 49, n. 1, p. 19-38, 1984.

HOWE, Louise K. Pink collar workers: inside the world of women's work. New York: Putnam Publishing Group, 1977. 
IBGE. Manual de Entrevista da Pesquisa Básica da PNAD de 1995. Rio de Janeiro: Instituto Brasileiro de Geografia e Estatística, 1995.

KIM, Chang Hwan; SAKAMOTO, Arthur. The rise of intra-occupational wage inequality in the United States, 1983 to 2002. American Sociological Review, 73, p. 129-157, 2008.

MAIA, Alexandre Gori; GARCIA, Vinicius Gaspar. Desigualdade e discriminação segundo gênero e raça no mercado de trabalho brasileiro. Revista da ABET, 6, p. 133-153, 2007.

MAIA, Alexandre Gori. Estrutura de ocupações e distribuição de rendimentos: uma análise da experiência brasileira nos anos 2000. Revista de Economia Contemporânea, 17, p. 276-301, 2013.

MILLS, Wright. White collar: the American middle classes. New York: Oxford Univ., 1956.

MOUW, Ted; KALLEBERG, Arne L. Occupations and the structure of wage inequality in the United States, 1980s to 2000s. American Sociological Review, v. 75, n. 3, p. 402-431, 2010.

PORTES, Alejandro; HOFFMANN, Kelly. Latin American class structures: their composition and change during the neoliberal era. Latin American Research Review, v. 38, n. 1, p. 41-82, 2003.

QUADROS, Waldir; MAIA, Alexandre Gori. Estrutura sócio-ocupacional no Brasil. Revista de Economia Contemporânea, v. 14, n. 3, p. 443-468, 2010.

ROSE, David; PEVALIN, David J. The national statistics socio-economic classification: unifying official and sociological approaches to the conceptualization and measurement of social class. Colchester: University of Essex, 2001. (ISER Working Papers. Paper 2001-4).

ROSE, David; HARRISON, Eric (Ed.). Social class in Europe: an introduction to the European socio-economic classification. London: Routledge, 2009. 324p.

SAKAMOTO, Arthur; POWERS, Daniel A. Demography of social stratification. In: POSTON, Dudley (Ed.). Handbook of population. New York: Kluwer Academic/Plenum Publisher, 2003.

SCHMIDT, Peter; STRAUSS, Robert P. The prediction of occupation using multiple logit models. International Economic Review, v. 16, n. 2, p. 471-486, 1975.

SHANK, Susan. Women and the labor market: the link grows stronger. Monthly Labor Review, v. 111, n. 3, p. 3-8, 1988.

SORENSEN, Aage B. The structural basis of Social Inequality. The American Journal of Sociology, v. 101, n. 5, 1996. 
SZELÉNYI, Szonja. Economic subsystems and the occupational structure: a comparison of Hungary and the United States. Sociological Forum, v. 7, n. 4, p. 563-586, 1992.

TOMASKOVIC-DEVEY, Donald; ZIMMER, Catherine; STAINBACK, Kevin; ROBINSON, Corre; TAYLOR, Tiffany. Documenting desegregation: segregation in American workplaces by race, ethnicity, and sex, 1966-2003. American Sociological Review, 71, p. 565, 2006.

WEEDEN, Kim. Why do some occupations pay more than others? Social closure and earnings inequality in the United States. American Journal of Sociology, v. 108, n. 1, p. 55-101, 2002.

WILLIAMS, Gregory. The changing U.S. labor force and occupational differentiation by sex. Demography, v. 16, n. 1, p. 73-87, 1979.

WRIGHT, Erik. Classes. London: Verso, 1985. 
Appendix A - Occupational Structure - Brazil 1983 and 2001

\begin{tabular}{|c|c|c|c|c|c|}
\hline \multirow{2}{*}{$\begin{array}{c}\text { Occupational } \\
\text { Group }\end{array}$} & \multirow{2}{*}{ Occupation } & \multicolumn{2}{|c|}{1983} & \multicolumn{2}{|c|}{2001} \\
\hline & & $\mathbf{N}(1.000 s)$ & $\%$ & $\mathbf{N}(1.000 s)$ & $\%$ \\
\hline \multirow{6}{*}{ Managers } & Managers and administrators, trading proprietors & 446 & 19.3 & 1,053 & 23.7 \\
\hline & Managers/supervisors, general office & 373 & 16.1 & 550 & 12.4 \\
\hline & Managers and administrators, trade & 201 & 8.7 & 510 & 11.5 \\
\hline & Managers and administrators, proprietors n.e.c. & 218 & 9.4 & 480 & 10.8 \\
\hline & Director, public service & 211 & 9.1 & 429 & 9.7 \\
\hline & Total & 2,311 & 100.0 & 4,438 & 100.0 \\
\hline \multirow{6}{*}{ Professionals } & Elementary and middle school teachers & 818 & 26.1 & 1,410 & 20.8 \\
\hline & Nurses (no diploma) & 303 & 9.7 & 634 & 9.3 \\
\hline & Secondary school teachers & 117 & 3.7 & 351 & 5.2 \\
\hline & Lawyers & 86 & 2.7 & 297 & 4.4 \\
\hline & Physicians & 114 & 3.6 & 271 & 4.0 \\
\hline & Total & 3,140 & 100.0 & 6,787 & 100.0 \\
\hline \multirow{6}{*}{$\begin{array}{l}\text { Administrative } \\
\text { Support }\end{array}$} & Administrative support workers & 1,767 & 47.8 & 1,770 & 33.4 \\
\hline & Recepcionists & 183 & 5.0 & 842 & 15.9 \\
\hline & Secretaries & 312 & 8.5 & 487 & 9.2 \\
\hline & Administrative assistants & 222 & 6.0 & 323 & 6.1 \\
\hline & Accounting assistants & 124 & 3.4 & 268 & 5.1 \\
\hline & Total & 3,693 & 100.0 & 5,304 & 100.0 \\
\hline \multirow{6}{*}{ Sales } & Salespersons & 1,325 & 33.2 & 3,225 & 35.8 \\
\hline & Trading self-employed & 1,150 & 28.8 & 2,420 & 26.8 \\
\hline & Street vendors (peddlers) & 384 & 9.6 & 1,256 & 13.9 \\
\hline & Cashiers & 187 & 4.7 & 482 & 5.3 \\
\hline & Travelling salespersons & 210 & 5.3 & 278 & 3.1 \\
\hline & Total & 3,987 & 100.0 & 9,019 & 100.0 \\
\hline
\end{tabular}


Continuação

\begin{tabular}{|c|c|c|c|c|c|}
\hline \multirow{2}{*}{$\begin{array}{c}\text { Occupational } \\
\text { Group }\end{array}$} & \multirow{2}{*}{ Occupation } & \multicolumn{2}{|c|}{1983} & \multicolumn{2}{|l|}{2001} \\
\hline & & $\mathbf{N}(\mathbf{1 . 0 0 0 s})$ & $\%$ & $\mathbf{N}(1.000 s)$ & $\%$ \\
\hline \multirow{6}{*}{ Services } & Service workers, n.e.c. & 634 & 24.2 & 1,986 & 32.9 \\
\hline & Cooks & 340 & 13.0 & 916 & 15.2 \\
\hline & Bartenders & 299 & 11.4 & 444 & 7.3 \\
\hline & Hairdressers & 95 & 3.6 & 384 & 6.3 \\
\hline & Security guards & 134 & 5.1 & 333 & 5.5 \\
\hline & Total & 2,619 & 100.0 & 6,043 & 100.0 \\
\hline \multirow{6}{*}{$\begin{array}{l}\text { Blue-collar } \\
\text { Workers }\end{array}$} & Drivers & 1,368 & 9.4 & 2,478 & 12.0 \\
\hline & Masons & 1,173 & 8.1 & 2,251 & 10.9 \\
\hline & Conservation and maintenance workers & 899 & 6.2 & 1,486 & 7.2 \\
\hline & Manual labor & 2,174 & 14.9 & 1,210 & 5.9 \\
\hline & Tailors, dressmakers and needleworkers & 870 & 6.0 & 1,201 & 5.8 \\
\hline & Total & 14,552 & 100.0 & 20,576 & 100.0 \\
\hline \multirow{2}{*}{$\begin{array}{l}\text { Private } \\
\text { Household }\end{array}$} & Private household workers & 2,656 & 100.0 & 5,670 & 100.0 \\
\hline & Total & 2,656 & 100.0 & 5,670 & 100.0 \\
\hline \multirow{6}{*}{ Farming } & Farm and ranch workers & 6,127 & 56.8 & 5,910 & 54.4 \\
\hline & Farmers and ranchers, self-employed & 3,416 & 31.7 & 3,721 & 34.2 \\
\hline & Farmers & 241 & 2.2 & 276 & 2.5 \\
\hline & Tractor drivers & 243 & 2.2 & 274 & 2.5 \\
\hline & Fishermen & 140 & 1.3 & 231 & 2.1 \\
\hline & Total & 10,783 & 100.0 & 10,873 & 100.0 \\
\hline
\end{tabular}

Source: PNAD, IBGE. 
Appendix A - Occupational Structure - Brazil 2002 and 2011

\begin{tabular}{|c|c|c|c|c|c|}
\hline \multirow{2}{*}{$\begin{array}{c}\text { Occupational } \\
\text { Group }\end{array}$} & \multirow{2}{*}{ Occupation } & \multicolumn{2}{|l|}{2002} & \multicolumn{2}{|l|}{2011} \\
\hline & & $\mathbf{N}(1.000 s)$ & $\%$ & $\mathbf{N}(1.000 s)$ & $\%$ \\
\hline \multirow{6}{*}{ Managers } & Industrial production managers & 2,191 & 49.4 & 2,302 & 50.0 \\
\hline & Support area managers & 750 & 16.9 & 752 & 16.3 \\
\hline & Directors, business (employers) & 625 & 14.1 & 619 & 13.5 \\
\hline & Managers/supervisors of offices and adm. support & 226 & 5.1 & 240 & 5.2 \\
\hline & Managers/supervisors of account. and financ. services & 172 & 3.9 & 225 & 4.9 \\
\hline & Total & 4,436 & 100.0 & 4,603 & 100.0 \\
\hline \multirow{6}{*}{ Professionals } & Elementary and middle school teachers & 1,412 & 19.7 & 1,596 & 15.3 \\
\hline & Nurses & 459 & 6.4 & 820 & 7.9 \\
\hline & Secondary school teachers & 310 & 4.3 & 626 & 6.0 \\
\hline & Lawyers & 346 & 4.8 & 574 & 5.5 \\
\hline & Designer, industry and arts & 278 & 3.9 & 474 & 4.6 \\
\hline & Total & 7,174 & 100.0 & 10,401 & 100.0 \\
\hline \multirow{6}{*}{$\begin{array}{l}\text { Administrative } \\
\text { Support }\end{array}$} & Administrative assistants & 1,630 & 27.0 & 3,065 & 36.4 \\
\hline & Receptionists & 639 & 10.6 & 1,077 & 12.8 \\
\hline & Secretaries & 623 & 10.3 & 719 & 8.5 \\
\hline & Stock clerks and order fillers & 454 & 7.5 & 664 & 7.9 \\
\hline & Accountants and auditors & 221 & 3.7 & 411 & 4.9 \\
\hline & Total & 6,028 & 100.0 & 8,413 & 100.0 \\
\hline \multirow{6}{*}{ Sales } & Salespersons and demonstrators & 4,847 & 54.8 & 8,086 & 68.6 \\
\hline & Street vendors (peddlers) & 1,662 & 18.8 & 1,127 & 9.6 \\
\hline & Sales representatives & 833 & 9.4 & 717 & 6.1 \\
\hline & Door-to-door sales workers & 103 & 1.2 & 374 & 3.2 \\
\hline & Cashiers and ticket sellers & 521 & 5.9 & 313 & 2.7 \\
\hline & Total & $\mathbf{8 , 8 4 5}$ & 100.0 & 11,793 & 100.0 \\
\hline
\end{tabular}




\begin{tabular}{|c|c|c|c|c|c|}
\hline \multirow{2}{*}{$\begin{array}{c}\text { Occupational } \\
\text { Group }\end{array}$} & \multirow{2}{*}{ Occupation } & \multicolumn{2}{|l|}{2002} & \multicolumn{2}{|l|}{2011} \\
\hline & & $\mathbf{N}(\mathbf{1 . 0 0 0 s})$ & $\%$ & $\mathbf{N}(1.000 s)$ & $\%$ \\
\hline \multirow{6}{*}{ Services } & Waiters and waitresses & 1,398 & 18.3 & 1,917 & 19.3 \\
\hline & Cooks & 993 & 13.0 & 1,545 & 15.6 \\
\hline & Hairdressers and personal appear. workers & 968 & 12.7 & 1,490 & 15.0 \\
\hline & Security guards & 1,024 & 13.4 & 1,027 & 10.3 \\
\hline & Service workers, n.e.c. & 739 & 9.7 & 937 & 9.4 \\
\hline & Total & 7,634 & 100.0 & 9,923 & 100.0 \\
\hline \multirow{6}{*}{$\begin{array}{l}\text { Blue-collar } \\
\text { Workers }\end{array}$} & Masons & 1,683 & 8.1 & 2,839 & 11.2 \\
\hline & Construction laborers & 1,354 & 6.5 & 2,181 & 8.6 \\
\hline & Conservation and maintenance workers & 1,833 & 8.8 & 1,870 & 7.4 \\
\hline & Driver/sales workers and truck drivers & 1,142 & 5.5 & 1,830 & 7.2 \\
\hline & Dressmakers and sewers & 1,004 & 4.8 & 1,211 & 4.8 \\
\hline & Total & 20,757 & 100.0 & 25,413 & 100.0 \\
\hline \multirow{6}{*}{$\begin{array}{l}\text { Private } \\
\text { Household }\end{array}$} & Maids and housekeeping cleaners & 5,374 & 91.2 & 5,425 & 83.6 \\
\hline & Child and elderly care workers & 387 & 6.6 & 819 & 12.6 \\
\hline & Cooks & 39 & 0.7 & 124 & 1.9 \\
\hline & Driver/private transportation & 55 & 0.9 & 56 & 0.9 \\
\hline & Manager/supervisor maids and housek. workers & 8 & 0.1 & 21 & 0.3 \\
\hline & Total & 5,895 & 100.0 & 6,488 & $\mathbf{1 0 0 . 0}$ \\
\hline \multirow{6}{*}{ Farming } & Agricultural workers & 3,452 & 29.6 & 3,054 & 33.4 \\
\hline & Farmers (agriculture) & 3,343 & 28.7 & 2,382 & 26.1 \\
\hline & Ranch animal farmworkers & 1,286 & 11.0 & 1,164 & 12.7 \\
\hline & Ranchers (cattle) & 915 & 7.9 & 652 & 7.1 \\
\hline & Farmers and ranchers, n.e.c. & 20 & 0.2 & 504 & 5.5 \\
\hline & Total & 11,652 & 100.0 & 9,138 & 100.0 \\
\hline
\end{tabular}

Source: PNAD, IBGE. 
Appendix A - Occupational Structure - US 1983 and 2002

\begin{tabular}{|c|c|c|c|c|c|}
\hline \multirow{2}{*}{$\begin{array}{c}\text { Occupational } \\
\text { Group }\end{array}$} & \multirow{2}{*}{ Occupation } & \multicolumn{2}{|l|}{1983} & \multicolumn{2}{|l|}{2002} \\
\hline & & $\mathbf{N}(\mathbf{1 . 0 0 0 s})$ & $\%$ & $\mathbf{N}(\mathbf{1 . 0 0 0 s})$ & $\%$ \\
\hline \multirow{6}{*}{ Managers } & Managers and administrators, n.e.c & 5,379 & 64.5 & 7,976 & 49.6 \\
\hline & Managers, food serving and lodging establishments & & & 1,585 & 9.9 \\
\hline & Managers, medicine and health & 94 & 1.1 & 869 & 5.4 \\
\hline & Administrators, education and related fields & 413 & 4.9 & 837 & 5.2 \\
\hline & Financial managers & 370 & 4.4 & 831 & 5.2 \\
\hline & Total & 8,345 & 100.0 & 16,068 & 100.0 \\
\hline \multirow{6}{*}{ Professionals } & Teachers, elementary school & 1,504 & 9.2 & 2,447 & 9.0 \\
\hline & Registered nurses & 1,269 & 7.8 & 2,236 & 8.2 \\
\hline & Computer systems analysts and scientists & 265 & 1.6 & 1,816 & 6.7 \\
\hline & Teachers, secondaty school & 1,317 & 8.1 & 1,370 & 5.0 \\
\hline & Teachers, others & 418 & 2.6 & 982 & 3.6 \\
\hline & Total & 16,287 & 100.0 & 27,214 & 100.0 \\
\hline \multirow{6}{*}{$\begin{array}{l}\text { Administrative } \\
\text { Support }\end{array}$} & Secretaries & 3,886 & 21.2 & 2,309 & 10.2 \\
\hline & Accountants and auditors & 1,133 & 6.2 & 1,676 & 7.4 \\
\hline & Bookkeepers, accountants, and auditing clerks & 1,993 & 10.9 & 1,627 & 7.2 \\
\hline & Investigators and adjusters, except insurance & 264 & 1.4 & 1,148 & 5.1 \\
\hline & Receptionists & 574 & 3.1 & 1,132 & 5.0 \\
\hline & Total & 18,290 & 100.0 & 22,651 & 100.0 \\
\hline \multirow{6}{*}{ Sales } & Supervisors and Proprietors, Sales Occupations & 2,912 & 25.4 & 4,695 & 30.7 \\
\hline & Cashiers & 1,886 & 16.4 & 2,918 & 19.1 \\
\hline & Sales representatives & 1,427 & 12.4 & 1,503 & 9.8 \\
\hline & Sales workers, other commodities & 1,426 & 12.4 & 1,496 & 9.8 \\
\hline & Real estate sales occupations & 511 & 4.4 & 817 & 5.3 \\
\hline & Total & 11,484 & 100.0 & 15,282 & 100.0 \\
\hline
\end{tabular}


Continuação

\begin{tabular}{|c|c|c|c|c|c|}
\hline \multirow{2}{*}{$\begin{array}{c}\text { Occupational } \\
\text { Group }\end{array}$} & \multirow{2}{*}{ Occupation } & \multicolumn{2}{|l|}{1983} & \multicolumn{2}{|c|}{2002} \\
\hline & & $\mathbf{N}(1.000 s)$ & $\%$ & $\mathrm{~N}(\mathbf{1 . 0 0 0 s})$ & $\%$ \\
\hline \multirow{6}{*}{ Services } & Janitors and cleaners & 2,051 & 15.6 & 2,322 & 11.9 \\
\hline & Nursing aides, orderlies and attendants & 1,281 & 9.8 & 2,310 & 11.8 \\
\hline & Cooks & 1,296 & 9.9 & 2,283 & 11.7 \\
\hline & Waiters and waitresses & 1,334 & 10.2 & 1,432 & 7.3 \\
\hline & Guards and police, except public service & 607 & 4.6 & 940 & 4.8 \\
\hline & Total & 13,130 & 100.0 & 19,563 & 100.0 \\
\hline \multirow{6}{*}{$\begin{array}{l}\text { Blue-collar } \\
\text { workers }\end{array}$} & Truck drivers & 1,664 & 6.2 & 3,215 & 10.1 \\
\hline & Carpenters & 1,027 & 3.8 & 1,468 & 4.6 \\
\hline & Laborers (except construction) & 1,066 & 3.9 & 1,265 & 4.0 \\
\hline & Stock handlers and baggers & 696 & 2.6 & 1,152 & 3.6 \\
\hline & Assemblers & 1,010 & 3.7 & 1,151 & 3.6 \\
\hline & Total & 27,043 & 100.0 & 31,732 & 100.0 \\
\hline \multirow{6}{*}{$\begin{array}{l}\text { Private } \\
\text { Household }\end{array}$} & Private household cleaners and servants & 539 & 41.4 & 462 & 66.0 \\
\hline & Child care workers & 724 & 55.6 & 219 & 31.3 \\
\hline & Cooks & 23 & 1.7 & 11 & 1.6 \\
\hline & Housekeepers and butlers & 15 & 1.1 & 6 & 0.9 \\
\hline & Laundry and dry-cleaning & 1 & 0.1 & 1 & 0.2 \\
\hline & Total & 1,301 & 100.0 & 699 & 100.0 \\
\hline \multirow{6}{*}{ Farming } & Farmers (except horticultural) & 1,298 & 47.3 & 948 & 42.6 \\
\hline & Farm workers & 993 & 36.2 & 634 & 28.5 \\
\hline & Supervisors, related agricultural occupations & 113 & 4.1 & 154 & 6.9 \\
\hline & Managers, farms, except horticultural & 50 & 1.8 & 153 & 6.9 \\
\hline & Graders and sorters, agricultural products & 20 & 0.7 & 68 & 3.1 \\
\hline & Total & 2,743 & 100.0 & 2,225 & 100.0 \\
\hline
\end{tabular}

Source: March supplement. 
Appendix A - Occupational Structure - US 2002 and 2011

\begin{tabular}{|c|c|c|c|c|c|}
\hline \multirow{2}{*}{$\begin{array}{c}\text { Occupational } \\
\text { Group }\end{array}$} & \multirow{2}{*}{ Occupation } & \multicolumn{2}{|c|}{2003} & \multicolumn{2}{|c|}{2011} \\
\hline & & $\mathbf{N}(\mathbf{1 . 0 0 0 s})$ & $\%$ & $\mathbf{N}(\mathbf{1 . 0 0 0 s})$ & $\%$ \\
\hline \multirow{6}{*}{ Managers } & Managers, general & 3,888 & 26.0 & 3,091 & 19.9 \\
\hline & Chief executives & 1,469 & 9.8 & 1,588 & 10.2 \\
\hline & Managers/supervisors of offices and adm. support & 1,497 & 10.0 & 1,488 & 9.6 \\
\hline & Financial managers & 1,051 & 7.0 & 1,143 & 7.3 \\
\hline & Food service managers & 835 & 5.6 & 1,007 & 6.5 \\
\hline & Total & 14,961 & 100.0 & 15,568 & 100.0 \\
\hline \multirow{6}{*}{ Professionals } & Elementary and middle school teachers & 2,500 & 8.9 & 2,926 & 9.2 \\
\hline & Registered nurses & 2,359 & 8.4 & 2,747 & 8.6 \\
\hline & Postsecondary teachers & 1,232 & 4.4 & 1,433 & 4.5 \\
\hline & Secondary school teachers & 1,098 & 3.9 & 1,155 & 3.6 \\
\hline & Lawyers, Judges, magistrates, and other judicial work & 1,000 & 3.6 & 1,151 & 3.6 \\
\hline & Total & 28,147 & 100.0 & $\mathbf{3 1 , 8 2 4}$ & 100.0 \\
\hline \multirow{6}{*}{$\begin{array}{l}\text { Administrative } \\
\text { Support }\end{array}$} & Secretaries and administrative assistants & 3,717 & 15.6 & 2,993 & 13.1 \\
\hline & Customer service representatives & 1,645 & 6.9 & 1,861 & 8.2 \\
\hline & Accountants and auditors & 1,746 & 7.3 & 1,706 & 7.5 \\
\hline & Stock clerks and order fillers & 1,457 & 6.1 & 1,611 & 7.1 \\
\hline & Bookkeeping, accountants, and auditing clerks & 1,583 & 6.7 & 1,318 & 5.8 \\
\hline & Total & 23,772 & 100.0 & 22,799 & 100.0 \\
\hline \multirow{6}{*}{ Sales } & Managers/supervisors of retail sales workers & 3,285 & 21.1 & 3,201 & 21.7 \\
\hline & Cashiers & 2,915 & 18.8 & 3,143 & 21.3 \\
\hline & Retail salespersons & 3,095 & 19.9 & 3,067 & 20.8 \\
\hline & Sales representatives, wholesale and manufacturing & 1,291 & 8.3 & 1,267 & 8.6 \\
\hline & Managers/supervisors of non-retail sales workers & 1,297 & 8.3 & 1,140 & 7.7 \\
\hline & Total & 15,541 & 100.0 & 14,751 & 100.0 \\
\hline
\end{tabular}


Continuação

\begin{tabular}{|c|c|c|c|c|c|}
\hline \multirow{2}{*}{$\begin{array}{c}\text { Occupational } \\
\text { Group }\end{array}$} & \multirow{2}{*}{ Occupation } & \multicolumn{2}{|c|}{2003} & \multicolumn{2}{|c|}{2011} \\
\hline & & $\mathbf{N}(1.000 s)$ & $\%$ & $\mathbf{N}(1.000 s)$ & $\%$ \\
\hline \multirow{6}{*}{ Services } & Janitors and building cleaners & 2,028 & 9.5 & 2,182 & 9.2 \\
\hline & Cooks & 1,987 & 9.3 & 1,984 & 8.4 \\
\hline & Nursing, psychiatric, and home health aides & 1,851 & 8.6 & 1,980 & 8.3 \\
\hline & Waiters and waitresses & 1,897 & 8.9 & 1,973 & 8.3 \\
\hline & Child care workers, except private household & 1,261 & 5.9 & 1,094 & 4.6 \\
\hline & Total & 21,428 & 100.0 & 23,730 & 100.0 \\
\hline \multirow{6}{*}{$\begin{array}{l}\text { Blue-collar } \\
\text { Workers }\end{array}$} & Driver/sales workers and truck drivers & 3,223 & 10.7 & 2,926 & 10.7 \\
\hline & Laborers and freight, stock and material movers & 1,677 & 5.6 & 1,697 & 6.2 \\
\hline & Carpenters & 1,472 & 4.9 & 1,303 & 4.8 \\
\hline & Construction laborers & 1,076 & 3.6 & 1,220 & 4.5 \\
\hline & Automotive service technicians and mechanics & 865 & 2.9 & 841 & 3.1 \\
\hline & Total & 30,121 & 100.0 & 27,307 & 100.0 \\
\hline \multirow{6}{*}{$\begin{array}{l}\text { Private } \\
\text { Household }\end{array}$} & Maids and housekeeping cleaners & 383 & 56.0 & 361 & 53.5 \\
\hline & Child care workers & 209 & 30.6 & 198 & 29.4 \\
\hline & Personal and home care aides & 76 & 11.1 & 79 & 11.7 \\
\hline & Personal care and service workers, all other & 1 & 0.2 & 23 & 3.4 \\
\hline & Janitors and building cleaners - private household & 2 & 0.2 & 7 & 1.1 \\
\hline & Total & 683 & 100.0 & 675 & 100.0 \\
\hline \multirow{6}{*}{ Farming } & Farmers and ranchers & 601 & 31.5 & 1,018 & 54.4 \\
\hline & Miscellaneous agricultural workers & 601 & 31.5 & 585 & 31.3 \\
\hline & Graders and sorters, agricultural products & 81 & 4.3 & 93 & 5.0 \\
\hline & Logging workers & 61 & 3.2 & 60 & 3.2 \\
\hline & Supervisors of agricultural workers & 55 & 2.9 & 50 & 2.7 \\
\hline & Total & 1,904 & 100.0 & 1,869 & 100.0 \\
\hline
\end{tabular}

Source: CPS, March supplement. 
Alexandre Gori Maia / Arthur Sakamoto

Appendix B - Percentage distribution and average values for the occupational structure according to personal characteristics Brazil and the US, 1982/1983 and 2009

\begin{tabular}{|c|c|c|c|c|c|c|c|c|c|c|c|}
\hline \multicolumn{3}{|c|}{ Occupational Structure } & \multirow{2}{*}{$\begin{array}{c}\text { Less than } \\
\begin{array}{c}\text { Elemen- } \\
\text { tary }\end{array} \\
35.7\end{array}$} & \multirow{2}{*}{$\begin{array}{c}\begin{array}{c}\text { Elemen } \\
\text {-tary }\end{array} \\
16.1\end{array}$} & \multirow{2}{*}{$\begin{array}{c}\begin{array}{c}\text { Secon- } \\
\text { dary }\end{array} \\
29.5\end{array}$} & \multirow{2}{*}{$\begin{array}{c}\text { Superior } \\
18.7\end{array}$} & \multirow{2}{*}{$\begin{array}{c}\text { Age } \\
16 \text { to } \\
29 \\
24.2\end{array}$} & \multirow{2}{*}{$\begin{array}{c}\text { Age } 30 \\
\text { to } 49 \\
57.2\end{array}$} & \multirow{2}{*}{$\begin{array}{c}\text { Age } 50 \\
\text { or more }\end{array}$} & \multirow{2}{*}{$\begin{array}{c}\text { Female } \\
17.0\end{array}$} & \multirow{2}{*}{$\begin{array}{r}\text { Black } \\
1.9\end{array}$} \\
\hline \multirow{18}{*}{ : } & \multirow{2}{*}{ Managers } & 1982 & & & & & & & & & \\
\hline & & 2011 & 11.1 & 10.5 & 42.8 & 35.5 & 18.9 & 56.9 & 24.2 & 37.3 & 4.2 \\
\hline & \multirow{2}{*}{ Professionals } & 1982 & 20.5 & 13.6 & 35.2 & 30.7 & 40.3 & 50.2 & 9.5 & 55.5 & 3.6 \\
\hline & & 2011 & 3.5 & 4.6 & 37.7 & 54.2 & 28.4 & 53.0 & 18.5 & 58.7 & 6.6 \\
\hline & \multirow{2}{*}{$\begin{array}{l}\text { Administrative } \\
\text { support }\end{array}$} & 1982 & 19.5 & 27.1 & 45.4 & 8.0 & 63.9 & 29.8 & 6.3 & 47.4 & 3.6 \\
\hline & & 2011 & 4.8 & 10.9 & 60.7 & 23.6 & 48.0 & 40.3 & 11.7 & 59.2 & 7.1 \\
\hline & \multirow{2}{*}{ Sales } & 1982 & 68.1 & 18.8 & 11.8 & 1.3 & 44.4 & 39.1 & 16.5 & 34.5 & 4.6 \\
\hline & & 2011 & 21.1 & 19.1 & 51.0 & 8.8 & 40.1 & 43.6 & 16.3 & 51.0 & 7.5 \\
\hline & \multirow{2}{*}{ Services } & 1982 & 78.2 & 11.5 & 8.6 & 1.6 & 40.8 & 43.4 & 15.7 & 53.9 & 9.6 \\
\hline & & 2011 & 28.5 & 22.7 & 43.7 & 5.2 & 29.7 & 51.5 & 18.7 & 50.0 & 10.9 \\
\hline & \multirow{2}{*}{$\begin{array}{l}\text { Blue-collar } \\
\text { workers }\end{array}$} & 1982 & 87.5 & 9.4 & 2.9 & 0.1 & 44.5 & 42.8 & 12.7 & 19.8 & 9.3 \\
\hline & & 2011 & 42.0 & 23.5 & 32.2 & 2.3 & 30.4 & 49.5 & 20.1 & 17.7 & 10.6 \\
\hline & \multirow{2}{*}{$\begin{array}{l}\text { Private } \\
\text { Household }\end{array}$} & 1982 & 94.2 & 5.1 & 0.7 & 0.0 & 57.6 & 31.6 & 10.8 & 93.1 & 17.1 \\
\hline & & 2011 & 55.4 & 23.6 & 20.0 & 1.0 & 20.3 & 56.5 & 23.2 & 92.6 & 13.2 \\
\hline & \multirow{2}{*}{ Farming } & 1982 & 97.2 & 1.9 & 0.7 & 0.2 & 41.9 & 35.9 & 22.3 & 20.8 & 8.4 \\
\hline & & 2011 & 74.5 & 13.7 & 10.4 & 1.4 & 24.3 & 42.6 & 33.0 & 21.0 & 8.9 \\
\hline & \multirow{2}{*}{ Total } & 1982 & 74.9 & 10.2 & 10.7 & 4.2 & 44.6 & 40.2 & 15.2 & 32.5 & 7.8 \\
\hline & & 2011 & 31.7 & 17.5 & 37.1 & 13.7 & 31.1 & 48.7 & 20.2 & 42.0 & 9.1 \\
\hline
\end{tabular}


Continuação

\begin{tabular}{|c|c|c|c|c|c|c|c|c|c|c|c|}
\hline & $\begin{array}{l}\text { Occupational } \\
\text { Structure }\end{array}$ & $\begin{array}{l}\text { Less than } \\
\text { Elemen- } \\
\text { tary }\end{array}$ & $\begin{array}{l}\text { Elemen- } \\
\text { tary }\end{array}$ & $\begin{array}{l}\text { Secon- } \\
\text { dary }\end{array}$ & Superior & $\begin{array}{c}\text { Age } 16 \\
\text { to } 29\end{array}$ & $\begin{array}{c}\text { Age } 30 \\
\text { to } 49\end{array}$ & $\begin{array}{l}\text { Age } 50 \\
\text { or more }\end{array}$ & Female & Black & \\
\hline \multirow{18}{*}{$\widetilde{\Omega}$} & \multirow{2}{*}{ Managers } & 1983 & 0.5 & 5.5 & 50.8 & 43.1 & 16.7 & 54.7 & 28.6 & 31.3 & 5.0 \\
\hline & & 2011 & 0.2 & 2.1 & 35.7 & 61.9 & 11.0 & 49.0 & 40.1 & 42.4 & 6.4 \\
\hline & \multirow{2}{*}{ Professionals } & 1983 & 0.1 & 1.7 & 30.8 & 67.3 & 27.8 & 51.9 & 20.3 & 47.3 & 6.3 \\
\hline & & 2011 & 0.1 & 0.9 & 17.8 & 81.3 & 18.2 & 48.1 & 33.8 & 56.9 & 9.0 \\
\hline & \multirow{2}{*}{$\begin{array}{l}\text { Administrative } \\
\text { support }\end{array}$} & 1983 & 0.3 & 5.3 & 76.2 & 18.3 & 35.9 & 43.1 & 21.0 & 75.2 & 8.7 \\
\hline & & 2011 & 0.3 & 3.4 & 51.8 & 44.5 & 23.1 & 42.8 & 34.1 & 68.2 & 11.8 \\
\hline & \multirow{2}{*}{ Sales } & 1983 & 1.4 & 10.9 & 65.6 & 22.1 & 38.5 & 37.9 & 23.6 & 47.6 & 4.6 \\
\hline & & 2011 & 0.8 & 7.7 & 55.8 & 35.8 & 31.3 & 38.1 & 30.6 & 50.4 & 9.6 \\
\hline & \multirow{2}{*}{ Services } & 1983 & 4.5 & 23.5 & 64.3 & 7.7 & 44.5 & 35.7 & 19.7 & 55.5 & 16.1 \\
\hline & & 2011 & 3.9 & 14.3 & 59.7 & 22.2 & 34.5 & 39.6 & 25.9 & 55.6 & 16.2 \\
\hline & \multirow{2}{*}{$\begin{array}{l}\text { Blue-collar } \\
\text { workers }\end{array}$} & 1983 & 4.1 & 24.6 & 66.6 & 4.7 & 35.4 & 43.7 & 21.0 & 18.9 & 10.7 \\
\hline & & 2011 & 4.3 & 13.4 & 65.5 & 16.8 & 21.7 & 47.4 & 30.9 & 14.0 & 10.6 \\
\hline & \multirow{2}{*}{$\begin{array}{l}\text { Private } \\
\text { Household }\end{array}$} & 1983 & 20.3 & 42.6 & 34.1 & 3.0 & 55.8 & 18.3 & 25.9 & 95.2 & 19.3 \\
\hline & & 2011 & 8.3 & 19.5 & 56.5 & 15.7 & 31.0 & 35.4 & 33.7 & 89.5 & 7.0 \\
\hline & \multirow{2}{*}{ Farming } & 1983 & 9.6 & 28.8 & 52.7 & 8.9 & 32.4 & 36.6 & 31.0 & 15.3 & 6.2 \\
\hline & & 2011 & 8.3 & 18.4 & 52.7 & 20.6 & 20.4 & 32.9 & 46.7 & 21.5 & 2.5 \\
\hline & \multirow{2}{*}{ Total } & 1983 & 2.5 & 14.2 & 59.9 & 23.3 & 34.4 & 43.6 & 22.0 & 44.2 & 9.1 \\
\hline & & 2011 & 1.8 & 7.2 & 46.7 & 44.2 & 23.2 & 44.4 & 32.4 & 47.5 & 10.7 \\
\hline
\end{tabular}

Source: PNAD, IBGE; CPS, March supplement. 